\title{
Lipid Sources in Diets for Hy-Line White Laying: Performance, Biometrics of Digestive Organs, and Bone Characteristics
}

\section{-Author(s)}

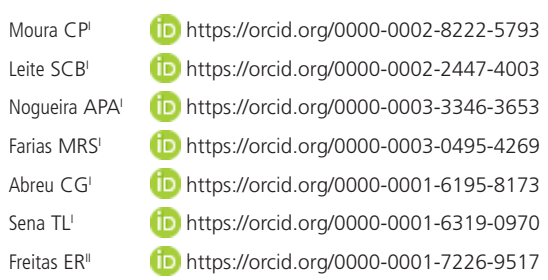

Universidade Estadual Vale do Acaraú, Centro de Ciências Agrárias e Biológicas, Curso de Zootecnia, Sobral, CE, Brasil.

" Universidade Federal do Ceará, Departamento de Zootecnia, Fortaleza, CE, Brasil.

\section{Mail Address}

Corresponding author e-mail address Silvana Cavalcante Bastos Leite

Avenida da Universidade, 850. Coordenação do Curso do Zootecnia, Betânia, Sobral,

Ceará, 62040-370, Brasil.

Phone: +55-88-36116359

Email: silvanabastos2000@yahoo.com.br

\section{- Keywords}

Energy feedstuff, cottonseed oil, laying, chicken fat.

\section{ABSTRACT}

Dietary inclusion of lipid sources has been one of the methods adopted by nutritionists aiming at better energy balancing. However, alternative energy feedstuffs have been sought in an attempt to reduce production costs. In this regard, lipid sources that can replace conventional ones, such as beef tallow, cottonseed oil, and sunflower oil have been investigated. The objective of this study was to examine the effects of different lipid sources on the performance, egg quality, biometrics of digestive organs, and bone quality of white-egg commercial layers in the first production cycle. A total of $216 \mathrm{Hy}$-Line White layers at 70 weeks of age, weighing $1.701 \pm 0.103 \mathrm{~kg}$, were used in a completely randomized design with four treatments and six replicates. The diets provided to them contained equal amounts of protein, calories, and amino acids, with only the lipid source varying - soybean oil (control), cottonseed oil, beef tallow, and sunflower oil. No significant effect of lipid sources was observed on any of the performance or egg-quality variables assessed $(p>0.05)$. Biometric variables were not influenced by lipid sources, except for abdominal fat, which was highest in the birds receiving the beef-tallow treatments and lowest in birds fed the sunflower-oil diets $(p<0.05)$. Except for mineral matter, bone traits were not influenced by the treatments; this variable was highest in the control treatments and lowest in the beef-tallow treatments. In conclusion, cottonseed and sunflower oils can be used to fully replace soybean oil in diets for white-egg commercial layers.

\section{INTRODUCTION}

In the agribusiness sector, poultry farming has had a marked growth in the last few years. Within this segment, the egg-laying branch has stood out, as verified by the increasing production of eggs at figures never-before seen in Brazil.

For decades, the most relevant components of poultry diets have been corn and soybean meal, the main energy and protein ingredients, respectively. However, as early-maturing animals, today's laying birds are more nutritionally demanding and have low feed-intake rates in their early production life. Thus, the dietary inclusion of lipid sources is a necessary measure to ensure their adequate energy intake (Silva et al., 2014).

Soybean oil has been the lipid source of choice in most poultry diets when the use thereof is a necessity. However, research shows that soybean oil addition to poultry diets should be made judiciously, since elevated levels of this ingredient may worsen eggshell quality (Jiang et al., 2014). According to Bavaresco et al. (2019), this is due to a likely interference with the mineral metabolism, mainly the calcium retention, through the formation of insoluble soaps during the digestion process. In this context, there has been an ever-growing 
interest in lipid ingredients that can satisfactory replace those commonly used in diets.

Plant-derived feedstuffs may present compounds called anti-nutritional factors. These are defined as compounds present in plant-based feedstuffs which reduce the nutritional value of these feedstuffs upon being consumed (Benevides et al., 2011). Gossypol is one of these factors; it is present in the seeds and by-products of cotton. Alexander et al. (2009) stated that cotton by-products may have some toxic effects, causing losses to poultry farming as a result of weight loss, decreased egg production, and reduced feed intake. Additionally, deleterious effects of it have been reported on organs like the liver and reproductive and immune systems (Gadelha et al., 2014). Because of the concern with the deleterious effects of anti-nutritional factors on animals, their biometrics is used as an instrument of investigation.

Therefore, possible substitutes such as beef tallow, cottonseed oil and sunflower oil, among others, may be viable options. In this scenario, the present study was conducted to evaluate the performance, egg-quality, biometrics of digestive organs, and bone quality of commercial white-egg layers in the first production cycle fed diets containing different lipid sources.

\section{MATERIAL AND METHODS}

The project was approved by the local ethics committee (approval no. 001.05.016.UVA.504.03). The experiment was carried out in the egg-laying unit of the Experimental Farm of the State University of Vale do Acaraú - UVA, located in Sobral - CE, for 84 days. A total of $216 \mathrm{Hy}$-Line White layers at 70 weeks of age, weighing $1.701 \pm 0.103 \mathrm{~kg}$, with an average production of $70.97 \% \pm 5.41$, were distributed into four treatments with six replicates of nine birds each, in a completely randomized experimental design.

Experimental diets contained equal amounts of protein, calories, and amino acids (Table 1) and were formulated following the nutritional requirements suggested by the manual of the strain. The composition of ingredients used in the formulation followed the recommendation of Rostagno et al. (2011). The nutritional composition of cottonseed meal was obtained from Lima et al. (2016), and that of sunflower seed from Fedna (2004).

Diets were formulated based on corn, soybean meal, a source of calcium and phosphorus, a vitaminmineral premix, common salt, and a lipid source, and divided into the following treatments: 1 - soybean oil; 2 - cottonseed oil (no ferrous sulfate supplementation); 3 - beef tallow; and 4 - sunflower oil.

Egg production was recorded daily until the end of each 28-day period, when these data, together with those of feed intake, were used for the calculation of performance variables. The following parameters were evaluated: feed intake (g/bird/day), egg production (\%), egg weight (g), egg mass (g/bird/day), feed conversion per egg mass $(\mathrm{kg} / \mathrm{kg})$, and feed conversion per dozen eggs $(\mathrm{kg} / \mathrm{dz})$.

Table 1 - Centesimal and calculated nutritional composition of experimental diets.

\begin{tabular}{|c|c|c|c|c|}
\hline \multirow{2}{*}{ Ingredient (kg) } & \multicolumn{4}{|c|}{ Lipid Source } \\
\hline & Soybean & Cottonseed & Beef Tallow & Sunflower \\
\hline Corn $(\mathrm{kg})$ & 61.459 & 60.723 & 60.406 & 61.291 \\
\hline Soybean meal (45\%) & 21.815 & 21.947 & 22.004 & 21.845 \\
\hline Limestone (kg) & 8.147 & 8.144 & 8.143 & 8.146 \\
\hline Meat meal $40 \%(\mathrm{~kg})$ & 5.473 & 5.479 & 5.481 & 5.475 \\
\hline Vitamin-mineral supplement $(\mathrm{kg})^{*}$ & 0.400 & 0.400 & 0.400 & 0.400 \\
\hline Common salt $(\mathrm{kg})$ & 0.272 & 0.272 & 0.272 & 0.272 \\
\hline Oil & 2.311 & 2.911 & 3.169 & 2.448 \\
\hline DL-methionine $(\mathrm{kg})$ & 0.121 & 0.121 & 0.122 & 0.121 \\
\hline Metabolizable energy (Kcal/kg) & 2900 & 2900 & 2900 & 2900 \\
\hline Crude protein (\%) & 17.50 & 17.50 & 17.50 & 17.50 \\
\hline Calcium (\%) & 4.000 & 4.000 & 4.000 & 4.000 \\
\hline Available phosphorus (\%) & 0.430 & 0.430 & 0.430 & 0.430 \\
\hline Sodium (\%) & 0.180 & 0.180 & 0.180 & 0.180 \\
\hline Digestible met + cys (\%) & 0.660 & 0.660 & 0.660 & 0.660 \\
\hline Digestible methionine (\%) & 0.415 & 0.415 & 0.415 & 0.415 \\
\hline Digestible lysine (\%) & 0.760 & 0.760 & 0.760 & 0.760 \\
\hline
\end{tabular}

*PX POSTURA 0.4\% 500 TEC - Guaranteedlevelsoftheproduct (composition per kg ofproduct): iron (min) - $10.00 \mathrm{~g} ;$ copper (min) - 2,500.00 mg; zinc (min) - $20.00 \mathrm{~g} ;$ manganese (min) - $20.00 \mathrm{~g}$; iodine (min) - 208.00 mg; selenium (min) - 75.15 mg; vitamin A (min) - 2,000,000.00 IU; vitamin D3 (min) - 625,000.00 IU; vitamin E (min) - 3,000.00; vitamin K3 (min) - 395.92 mg; folicacid (min) - 74.25 mg; choline (min) - 100.00 g; niacin (min) - 5,025.74 mg; pantothenicacid (min) - 1,805.16 mg; vitamin B1 (min) - 250.09 mg; vitamin B2 (min) - 1,000.00 mg; vitamin B6 (min) - 250.1 mcg; vitamin B12 (min) - 2,400.00; methionine (min) - 125.00 g; colistin (min) - 1,750.00 mg. 
At the end of each period, the following eggquality parameters were also assessed: percentages of albumen, yolk, and eggshell; yolk color; eggshell thickness $(\mathrm{mm})$; and egg specific gravity $\left(\mathrm{g} / \mathrm{cm}^{3}\right)$. Four eggs were selected per replicate, two of which for the determination of specific gravity and the other two for the other quality analyses.

The eggs were cracked manually, and its components were weighed separately. For the calculation of eggshell thickness, shells were left to dry for $24 \mathrm{~h}$, weighed, and then three measurements were taken from the equatorial region and extremities of the egg using a digital caliper.

Yolk color was determined subjectively by comparing it with the Roche ${ }^{\circledR}$ Yolk Color Fan, whose scores range from 1 to 15 , where the first represents the palest yellow and the last the most intense orange (Sandeski et al., 2014).

At the end of the experiment, 20 birds were chosen at random and identified (five per treatment). These were euthanized by the cervical-dislocation method and taken to the laboratory, where they were weighed individually and had their organs removed and emptied during a necropsy for biometric analyses of gizzard, liver, pancreas, and intestines, using a 0.01-g precision scale (adapted from Braz et al., 2011). All weight data were expressed as a percentage of body weight.

Only the tibiae were used in the evaluation of bone quality. The bone length was measured with a digital caliper, and its weight was determined on an electronic scale with $0.01 \mathrm{~g}$ precision. Bone density was obtained using the Seedor index, by dividing its weight (mg) by its length (mm) (Seedor et al., 1991).

Analyses of bone resistance and deformity were performed using a mechanical press, where the left tibiae were placed in horizontal position and then received a compression force onto their center. The maximum amount of force applied to the bone to its disruption was considered breaking resistance (kgf/ $\mathrm{cm}^{2}$ ), which was measured using a digital strain gauge. Deformity $(\mathrm{mm})$ was measured using an analogical strain gauge until the bone broke. These analyses took place in the Laboratory of Soil Mechanics at the Department of Transportation Engineering of the Federal University of Ceará.

Mineral matter (MM) was determined at the Laboratory of Animal Nutrition (LANUT) of UVA. After deboning, the right tibiae were weighed and dried in a forced-air oven at $105^{\circ} \mathrm{C}$ for $72 \mathrm{~h}$. Next, they were weighed and ground with a pestle and mortar. Ground samples were then identified for determination of the $\mathrm{MM}$ according to the methodology described by Silva \& Queiroz (2002).

The data were subjected to analysis of variance and means were compared by the Tukey test at the 5\% probability level, using the Statistical Analysis System software (SAS, 2000).

\section{RESULTS}

No effect of the evaluated lipid sources was observed on the performance variables (Table 2).

Table 2 - Mean values for feed intake, egg production, egg weight, egg mass, feed conversion per egg massand feed conversion per dozen eggs of Hy-line White commercial layers fed diets containing different lipid sources, in the period of 70 to 82 weeks of age.

\begin{tabular}{lcccccc}
\hline Lipid Source & Intake (g/bird/day) & Production $(\%)$ & Egg weight $(\mathrm{g})$ & Egg mass $(\mathrm{g} / \mathrm{b} / \mathrm{rd} / \mathrm{day})$ & $\mathrm{FCEM}{ }^{1}(\mathrm{~kg} / \mathrm{kg})$ & $\mathrm{FCDZ}(\mathrm{kg} / \mathrm{dz})$ \\
\hline Soybean control & 90.00 & 66.30 & 65.41 & 43.35 & 2.080 & 1.634 \\
Cottonseed & 90.56 & 62.76 & 65.25 & 41.00 & 2.224 & 1.737 \\
Beef tallow & 90.14 & 62.70 & 64.24 & 40.28 & 2.253 & 1.735 \\
Sunflower & 92.02 & 62.10 & 66.13 & 41.06 & 2.256 & 1.789 \\
Mean & 90.69 & 63.50 & 65.30 & 41.47 & 2.201 & 1.723 \\
\hline SEM & 0.839 & 0.534 & 0.227 & 0.370 & 0.031 & 0.023 \\
\hline$p$-value & 0.9450 & 0.1148 & 0.1230 & 0.1141 & 0.3557 \\
\hline
\end{tabular}

${ }^{1}$ Feed conversion per egg mass; ${ }^{2}$ Feed conversion per dozen eggs; ${ }^{3}$ Standard error of the mean.

None of the egg-quality variables was influenced ( $p>0.05$ ) by the lipid sources tested in this study (Table 3).

Irrespective of the lipid source used, no significant differences were found ( $p>0.05)$ for the relative weights of gizzard, liver, pancreas, and intestines. However, the abdominal fat was heavier in the birds from the treatments with beef tallow in relation to the diet containing sunflower oil $(p<0.05)$. The treatments including cottonseed and soybean oils, in turn, did not differ from the others (Table 4).

There was no effect of lipid sources on the bonequality variables, except for mineral matter, whose highest value was found in the control treatment 
Table 3 - Mean values for the percentages of albumen, yolk, and shell, eggshell thickness and specific gravity of Hy-line White layers fed diets containing lipid sources, in the period of 70 to 82 weeks of age.

\begin{tabular}{lcccccc}
\hline \multirow{2}{*}{ Lipid source } & \multicolumn{5}{c}{ Variable } \\
\cline { 2 - 7 } & \% Albumen & \% Yolk & \% Shell & Yolk color & $\mathrm{ET}^{1}\left(\mathrm{~mm}^{2}\right)$ & $\mathrm{SG}^{2}\left(\mathrm{~g} / \mathrm{cm}^{3}\right)$ \\
\hline Soybean Control & 61.22 & 26.70 & 8.48 & 6.82 & 0.372 & 1.084 \\
Cotton & 60.20 & 27.41 & 8.80 & 6.93 & 0.380 & 1.085 \\
Beef tallow & 60.00 & 27.97 & 8.47 & 6.96 & 0.370 & 1.083 \\
Sunflower & 60.28 & 27.31 & 8.51 & 6.80 & 0.372 & 1.083 \\
Mean & 60.43 & 27.38 & 8.57 & 6.87 & 0.373 & 1.084 \\
\hline SEM & 0.158 & 0.154 & 0.049 & 0.053 & 0.002 & 0.001 \\
\hline$p$-value & 0.2109 & 0.1088 & 0.1705 & 0.7758 & 0.5036 & 0.7685 \\
\hline
\end{tabular}

${ }^{1}$ Eggshell thickness; ${ }^{2}$ Specific gravity; ${ }^{3}$ Standard error of the mean.

Table 4 - Relative weight of the digestive organs of Hy-line Whitelayers fed diets containing lipid sources, in the period of 70 to 82 weeks of age.

\begin{tabular}{lccccc}
\hline \multirow{2}{*}{ Lipid source } & \multicolumn{3}{c}{ Variable } \\
\cline { 2 - 6 } & \% Gizzard & \% Liver & \% Pancreas & \% Intestine & \% Abdominal fat \\
\hline Soybean Control & 1.05 & 2.32 & 0.16 & 3.36 & $6.35 \mathrm{ab}$ \\
Cottonseed & 1.09 & 2.39 & 0.18 & 3.12 & $6.64 \mathrm{ab}$ \\
Beef tallow & 1.18 & 2.42 & 0.17 & 3.08 & $7.07 \mathrm{a}$ \\
Sunflower & 1.17 & 2.48 & 0.17 & 3.13 & $5.33 \mathrm{~b}$ \\
Mean & 1.21 & 2.40 & 0.17 & 3.17 & 6.35 \\
\hline SEM & 0.025 & 0.064 & 0.003 & 0.059 & 0.195 \\
\hline$p$-value & 0.4165 & 0.9386 & 0.5983 & 0.7188 & 0.0386 \\
\hline
\end{tabular}

'Standard error of the mean. Different letters in the same column differ statistically by the Tukey test at the $5 \%$ level.

(soybean oil) in comparison with the beef-tallow treatment. The diets containing cottonseed and sunflower oils, in turn, did not differ from the other treatments (Table 5)

Table 5 - Weight, length, Seedor Index (SI), resistance, deformity, and mineral matter of the tibiae of Hy-line White layers fed diets containing lipid sources, in the period of 70 to 82 weeks of age.

\begin{tabular}{lcccccc}
\hline \multirow{2}{*}{ Lipid source } & \multicolumn{7}{c}{ Variable } \\
\cline { 2 - 7 } & Weight $(\mathrm{g})$ & Length $(\mathrm{mm})$ & $\mathrm{SI}(\mathrm{mg} / \mathrm{mm})$ & Resistance $\left(\mathrm{kgf} / \mathrm{cm}^{2}\right)$ & Deformity $(\mathrm{mm})$ & Mineralmatter $(\mathrm{g} / \mathrm{kg})$ \\
\hline Soybean control & 7.06 & 113.00 & 62.46 & 7.36 & 1.42 & $54.69 \mathrm{a}$ \\
Cottonseed & 6.80 & 111.59 & 60.90 & 6.54 & 1.29 & $50.94 \mathrm{ab}$ \\
Beef tallow & 7.30 & 112.17 & 64.99 & 6.56 & 1.09 & $49.50 \mathrm{~b}$ \\
Sunflower & 7.12 & 114.17 & 62.34 & 6.87 & 1.27 & $51.26 \mathrm{ab}$ \\
Mean & 7.07 & 112.73 & 62.67 & 6.83 & 1.26 & 51.59 \\
\hline SEM & 0.081 & 0.380 & 0.564 & 0.230 & 0.056 & 0.552 \\
\hline$p$-value & 0.4900 & 0.3411 & 0.3428 & 0.7541 & 0.4501 & 0.0250 \\
\hline
\end{tabular}

${ }^{1}$ Seedor Index; ${ }^{2}$ Standard error of the mean. Different letters in the same column differ statistically by the Tukey test at the $5 \%$ level.

\section{DISCUSSION}

Oil addition to diets is normally indicated as a means to improve their palatability (Silva et al., 2014), consequently stimulating intake. However, in the present study, no alterations in feed intake were seen as a function of the tested lipid sources. Therefore, the lack of effects of such sources on the intake variable suggests that, at the levels used in the experimental diets, they may be indicated for use on a commercial scale.

As observed, none of the lipid sources affected egg production. This was likely because the layers used in the experiment were in the post-peak production, when their nutritional requirements are lower, and also because the diets contained equal amounts of energy and nutrients, ensuring adequate nutrient supply across all treatments, which led to the obtained results.

Oliveira et al. (2010) conducted two experiments with young layers (20 to 28 weeks), the second with birds in the post-peak phase (54 weeks) using lipid sources (soybean, sunflower, and linseed oils) and reported that, in the second trial, no performance variable was influenced by the tested lipid sources. These results are similar to those found in the present study. Conflicting results were reported by Küçükersan 
et al. (2010), who worked with sunflower, fish, soybean, and hazelnut oils and reported that the lowest egg production was obtained in the treatment with sunflower oil $(p<0.05)$.

Santos et al. (2009) used three lipid sources (soybean, linseed, and cottonseed oils) at the inclusion levels of 2 and $4 \%$ of the diets of white-egg layers and found that their performance was not influenced by the treatments.

Lima et al. (2016) used different levels of cottonseed oil $(0,2,4$, and $6 \%)$ with and without addition of ferrous sulfate in pre-starter diets (1 to 7 days) for broilers and reported that no effects of the treatments were observed on the performance variables.

According to Jiang et al. (2014), elevated levels of soybean oil (7 or $10 \%$ ) in the diet of brown-egg layers have detrimental effects on eggshell quality. In this study, no effect of the treatments was observed on the percentage of eggshell, eggshell thickness, or specific gravity, probably because the inclusion levels of the lipid sources tested here were lower than those mentioned by the above author.

In an experiment with commercial brown-egg layers at 36 weeks of age, Küçükersan et al. (2010) used 3\% of four different lipid sources (fish, sunflower, soybean, and hazelnut oils) and concluded that none of the eggquality parameters was influenced by the lipid sources.

Santos et al. (2009) used soybean, linseed, and cottonseed oils at the inclusion levels of 2 and $4 \%$ in experimental diets for white-egg layers and reported that the inclusion of vegetable oils in the diets, irrespective of the source, did not change the egg quality or its cholesterol level.

According to Sandeski et al. (2014), yolk color values higher than 8, as measured using the Roche yolk color fan, are overall preferred among consumers. In this experiment, despite the lack of differences $(p>0.05)$ between the treatments for this variable, the value was below that recommended by the afore-mentioned authors. The corn used in the experimental diets likely showed a lower xanthophyll content that led to the yolk color values found.

The diets used in this experiment were formulated so as to meet the nutritional requirements of the birds in the production stage in which they were. Therefore, there were no alterations in the nutritional levels of the diets across the treatments, and these factors might influence the weight and quality of the eggs, which did not occur. Because the only difference between the treatments was the lipid source, one may suggest that they did not interfere with the digestibility of the dietary nutrients, which promoted their use in the nutrition of commercial layers.

Although the data obtained in the present experiment showed that the different lipid sources were not able to improve the performance or egg quality of the commercial layers, these results are relevant, considering that they were similar to those obtained in the control group, containing soybean oil, an ingredient commonly used in the formulation of poultry diets but found at high prices in the market. In this way, the cottonseed and sunflower oils and beef tallow are viable alternative lipid sources in the feeding of commercial layers.

Gossypol is the anti-nutritional factor present at the largest concentration in the seeds of cotton ( $\mathrm{He}$ et al., 2015), released upon their processing. These compounds have a cumulative effects and cause liver degeneration (Gadelha et al., 2014), which is evidenced by an increase in the size of these organs, these effects being more pronounced in young animals. In the current experiment, the biometrics of digestive organs was not influenced by the treatments containing cottonseed oil, probably because the birds were at 70 weeks of age at the onset of the experiment and thus more resistant to the deleterious effects of the abovementioned anti-nutritional factors, coupled with the inclusion value of cottonseed oil in the diet, which did not reach $3 \%$.

Despite not being a commonly evaluated parameter in laying birds, the increase in abdominal fat found in these birds should be taken into account, mainly because laying birds deposit more abdominal fat as they age, and this excess fat may negatively affect the performance (Xing et al., 2009; Gewehr et al., 2011) and productive lifespan of those animals. Thus, factors favoring an increase in abdominal fat deposition should be avoided.

The type of lipid source used in the bird diets affects total body fat deposition (Fouad and ElSenousey, 2014), and the fatty acid profile of a feedstuff directly influences the digestibility of the lipid source. The increasing percentage of abdominal fat following the use of beef tallow may be related to the saturation level of the lipid source, since it is high in saturated fatty acids. Furthermore, as stated by Murakami et al. (2010), saturated fatty acids are less digestible when compared to unsaturated fatty acids.

Conflicting results were reported by Duarte et al. (2010), who worked with beef tallow (BT), degummed soybean oil (DSO), poultry viscera oil (PVO), BT + DSO, and PVO + DSO in broiler diets and found no effect of 
Lipid Sources in Diets for Hy-Line White Laying: Performance, Biometrics of Digestive Organs, and Bone Characteristics beef tallow alone or associated on the percentage of abdominal fat in the carcasses.

According to Mazzuco (2006), a decrease in the omega-6/omega-3 polyunsaturated fatty acids ratio may protect the body from loss of bone mass due to a reduction in the production of prostaglandin (PG), an eicosanoid involved in the stimulus to the boneresorption function. The lipid composition of soybean oil includes high concentrations of linoleic acid (56\%), besides oleic acid (23\%) and linolenic acid (5.21\%) (Faitarone et al., 2012). Thus, the above-mentioned composition of soybean oil led to the mineral matter results found in the tibiae.

Contrary results were reported by Potença et al. (2008), who worked with cottonseed oil, chicken viscera oil, beef tallow and their combinations with soybean oil in the feeding of broilers. Those authors evaluated bone-quality variables (Seedor Index and bone resistance) and concluded that the lipid sources did not influence the bone characteristics of the birds, regardless of being plant- or animal-derived.

Faitarone et al. (2012) evaluated the bone quality of commercial layers fed diets containing different lipid sources (linseed, canola, and soybean oils at the rates of $2.5 \%, 5 \%$, and their association at the rate of $2.5 \%$ of each lipid source). The researchers concluded that dietary supplementation of vegetable oils high in omega- 3 and omega- 6 polyunsaturated fatty acids did not influence the bone resistance of the layers or their bone formation/remodeling.

In conclusion, cottonseed and sunflower oils can be used to fully replace soybean oil in diets for commercial white-egg layers without affecting their performance, egg-quality, digestive organs, or bone quality.

\section{ACKNOWLEDGEMENTS}

To Tecnavic for the donation of materials; to Hy-line do Brasil for the donation of the chicks; and to CNPQ for the 'scientific initiation' fellowship grant.

\section{REFERENCES}

Alexander J, Benford D, Cockburn A, Cravedi JP, Dogliotti E, Domenico $A D$, et al. Scientific opinion of the panel on contaminants in the food chain on a request from the European Commission on Gossypol as undesirable substance in animal feed. The European Food Safety Authority Journal 2009;7(908):1-56.

Bavaresco C, Nunes AP, Forgiarini J, Alves DA, Xavier EG, Lopes DCN, et al. Morfometria intestinal e qualidade óssea de codornas japonesas alimentadas por um período prolongado com coprodutos do óleo de soja. Archives of Veterinary Science 2019;24(1):72-82.
Benevides CMJ, Souza MV, Souza RDB, Lopes MV. Fatores antinutricionais em alimentos:revisão. Segurança Alimentar e Nutricional 2011;18(2):6779.

Braz NM, Freitas ER, Bezerra RM, Cruz CEB, Farias NNP, Silva NM, et al. Fibra na ração de crescimento e seus efeitos no desempenho de poedeiras nas fases de crescimento e postura. Revista Brasileira de Zootecnia 2011;40(12):2744-2753.

Duarte FD, Lara LC, Baião NC, Cançado SV, Teixeira JL. Efeito da inclusão de diferentes fontes lipídicas em dietas para frangos de corte sobre o desempenho, rendimento e composição da carcaça. Arquivo Brasileiro de Medicina Veterinária e Zootecnia 2010;62(2):439-444.

Faitarone ABG, Garcia EA, Artoni SMB, Sgavioli S, Silva MDP, Gonçalves $\mathrm{HC}$, et al. Qualidade óssea de poedeiras comerciais leves alimentadas com rações suplementadas com diferentes óleos vegetais. Veterinária e Zootecnia 2012;19(3):356-365.

FEDNA - Fundación Española para el Desarrollo de la Nutrición Animal. Tablas of composition and nutritional value of feed materials. $2^{\text {nd }} \mathrm{ed}$. Madri; 2004. p.423.

Fouad AM, El-Senousey HK. Nutritional factors affecting abdominal fat deposition in poultry:a review. Asian-Australasian Journal of Animal Sciences 2014;27(7):1057-1068.

Gadelha ICN, Fonseca NBS, Oloris SCS, Melo MM, Soto-Blanco B. Gossypol toxicity from cottonseed products. Scientific World Journal 2014;2014:1-11.

Gewehr CE, Oliveira V, Costenaro J, Pagno G, Rosniecek M, Farias DK. Milho inteiro e moído em diferentes sistemas de alimentação para poedeiras semipesadas. Arquivo Brasileiro de Medicina Veterinária e Zootecnia 2011;63(6):1429-1436.

He T, Zhang HJ, Wang J, Wu SG, Yue HY, Qi GH. Application of lowgossypol cottonseed meal in laying hens' diet. Poultry Science 2015;94(10):2456-2463.

Jiang S, Cui LY, Hou JF, Shi C, Ke X, Yang LC, et al. Effects of age and dietary soybean oil level on eggshell quality, bone strength and blood biochemistry in laying hens. British Poultry Science 2014;55(5):653661.

Küçükersan K, Yeşilbağ D, Küçükersan S. Influence of different dietary oil sources on performance and cholesterol content of egg yolk in laying hen. Journal of Biodiversity and Environmental Sciences 2010;4(12):117-122.

Lima VBS, Dourado LRB, Machado LP, Biagiotti D, Lima SBP, Ferreira GJBC, et al. Cottonseed oil in diets for broilers in the pre-starter and starter phases. PlosOne 2016;11(1):1-13.

Mazzuco H. Integridade óssea em poedeiras comerciais: influência de dietas enriquecidas com ácidos graxos poli-insaturados e tipo de muda induzida [circular técnica, 47]. Concórdia: Embrapa Suínos e Aves; 2006.

Murakami KTT, Pinto MF, Ponsano EHG, Garcia Neto, M. Desempenho produtivo e qualidade da carne de frangos alimentados com ração contendo óleo de linhaça. Pesquisa Agropecuária Brasileira 2010;459(4):401-407.

Oliveira DD, Baião NC, Cançado SV, Figueiredo TC, Lara LC, Lana AMQ. Fontes de lipídios na dieta de poedeiras:desempenho produtivo e qualidade dos ovos. Arquivo Brasileiro de Medicina Veterinária e Zootecnia 2010;62(3):718-724.

Potença A, Murakami AE, Fernandes JIM, Matsushita M, Nakagawa EL. Performance, abdominal fat deposition and bone characteristics of broilers fed diets containing different lipid sources. Revista Brasileira de Ciência Avícola 2008;10(4):239-244. 
Moura CP, Leite SCB, Nogueira APA,

Farias MRS, Abreu CG, Sena TL, Freitas ER
Lipid Sources in Diets for Hy-Line White Laying: Performance, Biometrics of Digestive Organs, and Bone Characteristics

Silva DJ, Queiroz AC. Análise de alimentos: métodos químicos e biológicos. $3^{\mathrm{a}}$ ed. Viçosa: UFV; 2002.

Silva JHV, Pascoal LF, Lima RB, Lacerda PB, Oliveira AC. Digestão e absorção de lipídeos. In: Sakomura NK, Silva JHV, Costa FGP, Fernandes JBK, Hauschild L. Nutrição de não ruminantes. Jaboticabal: Funep; 2014. p.64-76.

Xing J, Kang L, Hu Y, Xu Q, Zhang N, Jiang Y. Effect of dietary betaine supplementation on mRNA expression and promoter $\mathrm{CpG}$ methylation of lipoprotein lipase gene in laying hens. Journal Poultry Science 2009;46(3):224-228.

SAS. User's guide: statistics. Version 10. Cary: SAS Institute; 2000.

Seedor JG, Quarraccio HH, Thompson DD. The biophosphonate alendronate (MK-217) inhibits bone loss due to ovariectomy in rats. Boné and Mineral Resources 1991;6(4):339-346. 
